\title{
COLABORAÇÃO PREMIADA: Aportes Teóricos e Jurisprudenciais, o Caso do Brasil e Inserções no Direito Comparado ${ }^{1}$
}

\author{
http://dx.doi.org/10.21527/2176-6622.2021.56.9359
}

Recebido em: 12/8/2019

Modificações solicitadas em: 26/11/2020

Aceito em: 2/2/2021

Fernando Soares Gomes

Autor correspondente. Universidade Estadual de Montes Claros (Unimontes) - Campus Universitário Prof. Darcy Ribeiro. Av. Prof. Rui Braga, s/n - Vila Mauriceia. Montes Claros/MG, Brasil. CEP 39401-089. http://lattes. cnpq.br/5070180403663898. https://orcid.org/0000-0003-1492-7192. fernandosg1502@gmail.com

Ian Bernar Santos Barroso Universidade Estadual de Montes Claros (Unimontes). Montes Claros/MG, Brasil.

\section{RESUMO}

O objetivo deste texto é analisar o instituto da colaboração premiada. Trata-se de uma abordagem qualitativa operacionalizada pela pesquisa bibliográfica e documental, com breve imersão em análise comparada. Observou-se que a colaboração premiada esteve presente em vários momentos na História e é um instituto que carrega imprecisões tanto sob o aspecto conceitual quanto classificatório, além do problema da dispersão normativa. No Direito comparado, considera-se a Itália como pioneira quanto à utilização do instituto. No Brasil, a colaboração premiada recebe tratamento na perspectiva constitucionalista, utilitarista e probatória. Conclui-se que a colaboração premiada é instrumento em transformação, especialmente relacionado a sua sistematização conceitual e a sua unificação normativa. Logo, embora o instrumento seja concretamente eficaz, é certo que, por vezes, determinados direitos dos colaboradores são desrespeitados.

Palavras-chave: Associação criminosa; colaboração premiada; dispersão normativa; utilitarismo; legitimidade probatória.

\section{PLEA BARGAIN: THEORETICAL AND JURISPRUDENTIAL APPROACHES,} THE BRAZILIAN CASE AND INCURSIONS IN COMPARATIVE LAW

\section{ABSTRACT}

The purpose of this paper is to analyze the institute of plea bargain. This is a qualitative work operationalized by bibliographic and documentary research, with an immersion in comparative analysis. Plea bargain was present at various times in history and it is an institute that carries inaccuracies in both conceptual and classificatory aspects, besides the problem of normative dispersion. In comparative law, Italy is a pioneer in the use of the institute. In Brazil, plea bargain receives treatment from a constitutional, utilitarian and probative perspective. It is concluded that the plea bargain is an instrument in transformation, especially related to its conceptual systematization and its normative unification. Therefore, although the instrument is concretely effective, it is certain that, at times, certain rights of employees are disregarded.

Keywords: Criminal association; plea bargain; normative dispersion; utilitarianism; probative legitimacy.

\footnotetext{
1 O presente trabalho é fruto de análises empreendidas no projeto de pesquisa "DELAÇÃO PREMIADA: percurso histórico e jurisprudencial no âmbito do Tribunal de Justiça do Estado de Minas Gerais", desenvolvido no período de março/2016 a março/2017, no contexto do Programa Institucional de Bolsas de Iniciação Científica da Fundação de Amparo à Pesquisa do Estado de Minas Gerais (Pibic/Fapemig).
} 


\section{Direito自 \\ Debate}

COLABORAÇÃO PREMIADA: APORTES TEÓRICOS E JURISPRUDENCIAIS, O CASO DO BRASIL E INSERÇÕES NO DIREITO COMPARADO Fernando Soares Gomes - Ian Bernar Santos Barroso - Leandro Luciano Silva Ravnjak

\section{INTRODUÇÃO}

A colaboração premiada é, atualmente, o centro de importantes controvérsias no âmbito da persecução criminal brasileira. Nota-se que o emprego, condições, homologação e operacionalização do instituto têm levantado discussões quanto a sua conveniência e validade jurídica.

O objetivo do presente estudo é analisar a legitimidade jurídica da colaboração premiada no Direito brasileiro. Nesta tendência, buscou-se verificar a compatibilidade do instrumento com a ordem constitucional, bem como a eficiência necessária para integrar as ferramentas investigativas sem comprometer o curso do processo.

Para atingir tal objetivo analisou-se a historicidade do instituto, seus elementos caracterizadores, suas variações conceituais e classificatórias e sua aproximação com o Direito estrangeiro.

A pesquisa bibliográfica e documental acerca dos institutos normativos relacionados direta e indiretamente à colaboração premiada foi essencial para a consecução do trabalho, inclusive utilizando a jurisprudência do Superior Tribunal de Justiça (STJ) e do Supremo Tribunal Federal (STF), além de breve imersão na análise comparada, especificamente o caso italiano e o estadunidense.

Após o percurso metodológico, constata-se que a colaboração premiada, apesar de somente ganhar notoriedade com os acontecimentos que envolvem a "Operação Lava Jato", ${ }^{2}$ esteve presente no ordenamento jurídico desde longa data, e que de lá até a atualidade sofreu transformações significativas que justificam sua análise mais detalhada.

No campo teórico, identificou-se as concepções doutrinárias que permeiam o instituto, especialmente as visões fundamentalista e utilitarista.

No âmbito normativo, evidenciou-se as consequências decorrentes da dispersão legislativa sobre a colaboração premiada, tanto sob o aspecto penal quanto o processual penal.

O resultado é a apresentação de uma contribuição para a ciência jurídica que não se preocupou em exaurir o tema, pelo contrário, o objetivo é desocultar elementos ainda pouco abordados no estudo da colaboração premiada, aprofundando-se na reflexão sobre a validade jurídica desta nas searas utilitarista, constitucional e probatória.

\section{TAXONOMIA JURÍDICA DA COLABORAÇÃO PREMIADA}

\subsection{Problematização conceitual da colaboração premiada}

Por colaboração premiada entende-se um mecanismo de investigação criminal no qual é proposto ao investigado a possibilidade de redução ou extinção da sua pena mediante colaboração de forma relevante com as investigações.

Embora a expressão "delação premiada" tenha sido comumente utilizada como sinônimo de colaboração premiada na doutrina, na jurisprudência e no ambiente midiático, esta variação é tecnicamente imprecisa. De acordo com o Dicionário Houaiss da Língua Portuguesa, o termo "delatar" tem o significado de "denunciar como responsável por crime" (HOUAISS; VILLAR, 2010, p.224). Jesus (2006, p. 50), por sua vez, afirma que "delação é a incriminação de terceiro, realizada por um suspeito, investigado, indiciado ou réu, no bojo de seu interrogatório (ou em outro ato)". Assim, a incorreção metodológica da expressão delação premiada para designar a totalidade do instrumento em estudo está na sua insuficiência e restrição. Isso por que a colaboração não se limita às situações de coautoria, somente como instrumento de indicação de novos alvos para as investigações, tratando-se de um instituto mais completo.

Operação policial-investigativa brasileira relacionada à lavagem de dinheiro e a corrupção. 
Um exemplo da inadequação do termo "delação" é o artigo $13^{3}$ da Lei Federal no 9.807/1999, que insere no âmbito da colaboração três situações que vão além da prática de denunciação de coautores, somando-se a isso a localização de vítimas e recuperação de produto do crime. 0 termo em questão abrange apenas a primeira hipótese elencada no artigo, não fazendo referência às ações previstas nos incisos II e III do dispositivo legal.

O termo "colaboração", por sua vez, possui a extensão conceitual necessária para se abarcar o instituto jurídico abordado. Colaborar significa "Trabalhar em comum com outrem na mesma obra" ou "Concorrer, cooperar para a realização de qualquer coisa". Desse modo, o indivíduo que localiza a vítima ou recupera parcialmente o produto do crime está colaborando, ainda que não esteja delatando ninguém, mesmo porque nem todos os crimes praticados possuem mais de um autor.

Assim sendo, ainda que a denominação "delação premiada" seja comumente utilizada, esta nomenclatura não representa o real significado do instrumento investigativo em análise, porquanto a terminologia "colaboração" é a mais adequada e, acertadamente, aquela adotada pela legislação.

\subsection{Classificação da colaboração premiada}

Apesar de não ser, tecnicamente, o termo correto para a designação do instituto em análise, a expressão delação premiada não merece ser banida do jargão jurídico. Isso porque, em uma análise classificatória, pode-se situar a delação premiada como uma espécie do gênero colaboração, tendo em vista a amplitude que o termo "colaboração" possui e a existência de outras espécies de colaboração, como cita a Lei no 9.807/1999 quando se refere à localização da vítima ou à recuperação do produto do crime, caráter reafirmado pelas Leis no $11.343 / 2006$ e $n=12.850 / 2013 .^{4}$

Tal classificação não é aceita de forma unânime na doutrina. ${ }^{5}$ Salienta-se, contudo, que essa separação apresenta um cunho taxonômico e informativo, necessário para que haja precisão nas ciências jurídicas, acompanhando-se o entendimento de Vladimir Aras (2013). No mesmo sentido, afirma Jesus (2006, p. 50) que "[...] há situações, como na Lei de Lavagem de Capitais (Lei no 9.613/1998), nas quais se conferem prêmios a criminosos, ainda que não tenham delatado terceiros, mas conduzam a investigação à localização de bens, direitos ou valores objetos do crime".

Nesse sentido, as denominações taxonômicas e as expressões utilizadas no mundo jurídico devem conter aspectos estritamente técnicos e que comprovem a real extensão e sentido das palavras, não se podendo atribuir a um termo um significado diferente daquele que corresponda à realidade científica por mera conveniência. Afinal de contas, a ciência da sociolinguística, que se ocupa em entender o contexto social e cultural da produção linguística, possui como um de seus objetivos entender "quais são os principais fatores que motivam a variação linguística e qual a importância desses fatores na configuração do quadro que se apresenta variável" (CEZÁRIO; VOTRE, 2015, p. 141).

\footnotetext{
"Art. 13. Poderá o juiz, de ofício ou a requerimento das partes, conceder o perdão judicial e a consequente extinção da punibilidade ao acusado que, sendo primário, tenha colaborado efetiva e voluntariamente com a investigação e o processo criminal, desde que dessa colaboração tenha resultado:

I - a identificação dos demais coautores ou partícipes da ação criminosa;

II - a localização da vítima com a sua integridade física preservada;

III - a recuperação total ou parcial do produto do crime".

4 Lei no 11.343/2006. "Art. 41. O indiciado ou acusado que colaborar voluntariamente com a investigação policial e o processo criminal na identificação dos demais coautores ou partícipes do crime e na recuperação total ou parcial do produto do crime, no caso de condenação, terá pena reduzida de um terço a dois terços." Lei no 12.850/2013. "Art. 4o - O juiz poderá, a requerimento das partes, conceder o perdão judicial, reduzir em até $2 / 3$ (dois terços) a pena privativa de liberdade ou substituí-la por restritiva de direitos daquele que tenha colaborado efetiva e voluntariamente com a investigação e com o processo criminal, desde que dessa colaboração advenha um ou mais dos seguintes resultados: [...]." Grifo.

5 Marcos Paulo Dutra Santos, em sua obra Colaboração (delação) Premiada, critica a tendência de alguns doutrinadores processuais criminais sistematizarem hierarquicamente a colaboração premiada, afirmando que "sustentar, da mesma forma, que a delação é espécie do gênero colaboração, porque a última não necessariamente deságua na primeira é outra imprecisão" (SANTOS, 2016).
} 
Conclui-se que a diferenciação entre colaboração premiada e delação premiada é tecnicamente precisa e deve ser levada em conta na doutrina e na jurisprudência, sob pena se cultivar um termo que, juridicamente, destoa da realidade.

Adotou-se neste trabalho a classificação apresentada por Vladimir Aras, que divide a colaboração premiada em delação premiada, colaboração preventiva, colaboração para recuperação e colaboração para localização de vítima. Todas essas espécies encontram-se expressas na Lei no 12.820/2013.

Além das classificações apresentadas pela obra de Vladimir Aras, identificou-se, na Convenção das Nações Unidas Contra a Corrupção (Convenção de Mérida) e na Convenção das Nações Unidas Contra o Crime Organizado Transnacional (Convenção de Palermo) outra forma de colaboração premiada. Denominou-se tal espécie como colaboração internacional, que se faz presente nos artigos 37.5 e 26.5 das mencionadas convenções, respectivamente.

Essa espécie de colaboração premiada ocorre quando o potencial colaborador de um crime apurado em um país está residindo em um outro. Caso esse colaborador possua problemas com a Justiça Criminal do país em que se encontra, poderá realizar um acordo em que irá contribuir com as investigações do primeiro país, recebendo o benefício naquele em que está.

É oportuno ressaltar que a colaboração internacional, embora pouco utilizada, pode ser de grande valia no combate ao crime organizado e à corrupção transnacional, principalmente aqueles relacionados ao tráfico internacional de entorpecentes e à lavagem de dinheiro, diariamente divulgados na mídia.

\section{NATUREZA JURÍDICA DA COLABORAÇÃO PREMIADA}

Superada a análise sobre os conceitos e as espécies da colaboração premiada, outra nota introdutória importante a ser analisada é a natureza jurídica da colaboração premiada. Perceptível, pelo fato de ser um instrumento da investigação criminal e por conceder benefício àqueles que estejam diante de um processo criminal, que a colaboração premiada possui natureza processual.

Mais especificamente, trata-se um negócio jurídico processual, o que já afirmado por Santos (2016) e pelo ministro do STF Dias Toffoli no julgamento do HC 127.483: "a colaboração premiada é um negócio jurídico processual, uma vez que, além de ser qualificada expressamente pela lei como 'meio de obtenção de prova', seu objeto é a cooperação do imputado para a investigação e para o processo criminal, atividade de natureza processual, ainda que se agregue a esse negócio jurídico o efeito substancial (de direito material) concernente à sanção premial a ser atribuída a essa colaboração".

Outra característica é que a colaboração premiada situa-se entre a confissão espontânea e o testemunho. Dessa forma, é razoável entender que algumas regras destes institutos devem se aplicar interpretativa e subsidiariamente, no que couber, à colaboração premiada, o que auxilia no caso de haver lacunas que poderiam tornar o processo de colaboração arbitrário ou desmedido, solução esta que, uma vez que aumenta o número de regras procedimentais aplicáveis ao instrumento colaboracional, torna-o mais seguro juridicamente aos colaboradores, e, portanto, mais legítimo.

Claro é que a colaboração premiada não possui a mesma força probatória que o testemunho, até porque não é prova, mas somente meio, contudo aproxima-se deste quando há a confirmação das declarações dadas no processo de colaboração por outras provas no processo.

Tendo em vista a impossibilidade da analogia in malam partem no Direito Penal, bem como o princípio da fragmentariedade, não se pode aplicar o tipo penal de falso testemunho ao colaborador que presta informações falsas. Existe, no entanto, para o caso uma espécie privilegiada do crime de falso testemunho descrita na própria Lei no 12.850/2013, que afirma em seu artigo 19: "Imputar falsamente, sob pretexto de colaboração com a Justiça, a prática de infração penal à pessoa que sabe ser inocente, ou revelar informações sobre a estrutura de organização criminosa que sabe inverídicas: Pena reclusão, de 1 (um) a 4 (quatro) anos, e multa".

Reputa-se como acertada a opção do legislador de criar uma figura privilegiada do crime de falso testemunho para o instituto em análise. Isso porque a colaboração premiada não possui a natureza e a força probatória que o testemunho tem, sendo somente meio de obtenção de provas, de forma que as declarações prestadas pelo colaborador são inúteis em um processo se não forem confirmadas por outras provas. Além 
disso, caso haja inveracidade das informações prestadas, embora seja lacunosa a Lei no 12.850/2013 a esse respeito, é racional entender que os benefícios concedidos serão revogados, constituindo, desde já, uma forma de sanção.

Neste tópico, é oportuno destacar uma das alterações promovidas no âmbito da Lei no 12.850/2013, pela recente Lei no 13.964/2019, sancionada em 24 de dezembro de 2019 e intitulada como "Pacote Anticrime", que objetivou "aperfeiçoar a legislação penal e processual penal". Ocorre que o referido Pacote promoveu a inclusão do artigo 3--A na Lei no 12.850/2013, estabelecendo uma espécie de pacificação do conceito de natureza jurídica do acordo de colaboração premiada, ao defini-lo como "negócio jurídico processual e meio de obtenção de prova, que pressupõe utilidade e interesse públicos".

Apesar do impacto doutrinário promovido pela aludida inclusão, Melo e Broeto (2019) apontam que "esse entendimento já estava mais que sedimentado pela doutrina e jurisprudência pátrias". Vale ressaltar, ainda, que "o sobredito dispositivo trata da natureza jurídica 'do acordo' de colaboração premiada em si, que não se confunde com a colaboração premiada propriamente dita", eis que o referido instituto "independe de acordo expresso", tratando-se, em verdade, "de uma 'postura' colaborativa a qual extrapola o mero firmamento de um instrumento contratual".

\section{REFLEXÕES NO ÂMBITO DO DIREITO COMPARADO}

Já consolidado em outras legislações, é importante que se faça um sucinto apanhado do funcionamento da colaboração premiada nesses países, levando-se em conta as peculiaridades de cada um, tal como a organização judiciária e o sistema jurídico adotado (civil law ou common law).

Além da legislação italiana como referência, buscou-se também amparo na lei americana, uma vez que a adoção do common law e a maior liberdade proporcionada ao promotor de Justiça naquela nação traz novas perspectivas à utilidade da colaboração premiada no Brasil.

\subsection{Breve histórico na Itália}

O Brasil não foi pioneiro na aplicação do instituto da colaboração premiada. No contexto estrangeiro, o instituto já está regulamentado e desenvolvido há mais tempo, especialmente na Itália e Estados Unidos.

O sistema de justiça negocial italiano está, histórica e fundamentalmente, ligado ao surgimento das denominadas máfias. O termo máfia foi empregado pela primeira vez em 1865 em uma conversa entre o prefeito da cidade de Palermo e o ministro do Interior, com o significado de associação delitiva. A máfia, em seu começo, era um componente da sociedade siciliana, representando, na prática, uma espécie de poder intermediário entre o Estado Italiano e a sociedade, principalmente em locais em que o Estado estava presente apenas formalmente (RODRIGUEZ, 2010). Bittar (2011, p. 299) explica que: "O processo de surgimento da máfia vem descrito [...] como o acordo entre a força pública e os criminosos para a recuperação dos bens roubados".

Há, assim, a primeira vinculação entre as organizações mafiosas e o poder político. Essa espécie de máfia, entretanto, denominada "velha máfia", foi acabando ao fim do século 19 e início do século 20, com as migrações sicilianas para os Estados Unidos, dando origem, em contrapartida, a grupos mafiosos em solo americano que tinha relação com a Sićlia.

Ainda que o fascismo tenha atacado fortemente a máfia, sua recuperação deu-se ao fim da Segunda Guerra Mundial, contexto no qual os Estados Unidos, objetivando facilitar o desembarque de suas tropas na Sicília, estabeleceu relações com a máfia americana de origem siciliana - cita-se, particularmente, o mafioso Lucky Luciano - colocando, assim, nos cargos políticos da Sicília pessoas ligadas à máfia (RODRIGUEZ, 2010).

Após todos esses acontecimentos, há uma reviravolta no papel da máfia na sociedade italiana. $\mathrm{O}$ acordo entre os criminosos e o Estado se finda, e aqueles passam a oferecer um serviço de proteção aos latifundiários. Explica Bittar (2011, p. 229): "veem-se chefões da máfia que se colocam no centro de uma propriedade e que dizem: garanto-lhes que aqui não haverá roubos, mas me deem um tanto por cento das suas colheitas".

Logo, uma das primeiras formas, se não a primeira, de crime organizado, expandiu-se assustadoramente. Tal expansão ocorreu não somente na Itália, mas em todo o mundo, inclusive no continente americano. 
Nesse conceito, o Estado Italiano se viu obrigado a desenvolver métodos que pudessem combater as organizações criminosas italianas, surgindo, assim, o instituto do pentitismo, ou arrependimento.

\subsection{Modelo atual de Justiça Premial Italiano}

Assim como no Brasil, segundo Santos (2016), a Constituição Italiana em seu artigo 112 impõe ao Ministério Público o dever de propor a ação penal pública, constituindo, portanto, o princípio da obrigatoriedade da ação penal. Decorre disso, juntamente com a adoção do sistema civil law, que o sistema italiano exige uma técnica legislativa mais descritiva do que o americano, principalmente em termos procedimentais.

Não obstante, não se deve deixar sem menção o fato de que, conforme Morello (2000), os promotores italianos não têm observado rigidamente o princípio da obrigatoriedade da ação penal. Isso porque o cotidiano italiano vem sendo gravado por diversos fatores que interferem no arranjo penal, como novas normas incriminadoras, fragilidade da polícia judiciária e intensa criminalidade em determinados segmentos, além de, por óbvio, a sobrecarga do Ministério Público Italiano. Os promotores, então, têm sido obrigados a selecionar as infrações que de fato merecem uma ação penal, adotando, na prática, o princípio da discricionariedade penal, ligando-se a um sistema mais utilitarista e flexível do que aquele descrito ortodoxamente na lei italiana.

O ordenamento jurídico italiano possui leis que abordam a colaboração premiada em seu aspecto material, como leis processuais e procedimentais que regem o tema. Basicamente, as leis materiais italianas garantem ao colaborador benefícios semelhantes aos que a lei brasileira garante. Ocorre que, durante o processo histórico, o Estado italiano realizou uma manobra legislativa na qual, ao mesmo tempo em que se endurecia as penas ou se criavam novos tipos penais para as ações ligadas às organizações criminosas, como extorsão mediante sequestro e delitos ligados ao terrorismo, buscou-se estabelecer maiores benefícios para os colaboradores. Essa estratégia fez com que os colaboradores não somente realizassem ativamente as colaborações, mas também se dissociassem do grupo criminoso, recuperando, portanto, os jovens associados a tais organizações (BITTAR, 2011).

Quanto aos procedimentos para a realização da colaboração premiada, a legislação italiana optou por diminuir as lacunas ao mínimo, criando, portanto, uma legislação que, em consonância com sistema processual italiano, disciplina as condutas de cada agente no processo de colaboração.

Não faltam exemplos de determinações legais acerca do procedimento da colaboração premiada na legislação italiana, verbi gratia, a necessidade de outros elementos que confirmem a autenticidade das colaborações, o direito a medidas específicas de proteção para o colaborador e sua família, como a substituição de seus documentos e a mudança de residência para locais protegidos, a obrigação de o colaborador não prestar informações a terceiros, a facilitação para que os colaboradores obtenham benefícios penitenciários, o instituto do Verbale ilustrativo, ${ }^{6}$ a distinção entre momento tutório e momentos premiais, ${ }^{7}$ entre outros incontáveis regramentos procedimentais.

Destarte, torna-se claro que este ordenamento possui uma proximidade maior com o sistema brasileiro de Justiça. Além disso, seu estudo é facilitado pela positivação dada ao instituto.

\subsection{Os Estados Unidos e o plea bargaining}

Diferentemente da Itália, e em decorrência do sistema common law, Santos (2016) esclarece que os Estados Unidos adotam o princípio da discricionariedade dos promotores em se tratando do exercício da ação penal pública, o chamado prosecutorial discretion. Dessa forma, nada pode fazer o Judiciário caso os promotores de Justiça decidam por arquivar um inquérito policial, fazendo com que o sistema de negociações entre acusação e defesa tenha uma dinâmica totalmente diferente do sistema italiano ou brasileiro, por exemplo (SANTOS, 2016).

\footnotetext{
Verbale illustrativo: Instrumento utilizado pelo Direito italiano pelo qual são realizadas as declarações da colaboração premiada.

Conforme Bittar (2011), no Direito italiano a colaboração premiada é realizada em duas fases: (1) o momento tutório, em que são garantidos direitos imediatos de proteção ao colaborador e (2) momento premial, em que é concedido o prêmio principal ao colaborador, qual seja, redução ou extinção de sua pena, por exemplo.
} 
A própria ideia de se usar como prova a cooperação de um coautor tem como uma de suas raízes nos ordenamentos jurídicos o modelo anglo-saxão. Assim, a adoção do princípio da oportunidade ou discricionariedade por tais ordenamentos facilita o uso de mecanismos como o plea of guilty e o plea bargaining (MAIER, 2004).

Nesse sentido, sabe-se que os Estados Unidos possuem uma regra federal para disciplinar o procedimento do plea bargaining, sendo a denominada Federal Rules of Criminal Procedure, Rule 11 - Pleas.

Constata-se que o réu possui três alternativas: declarar-se expressamente culpado - plea of guilty - afirmar que não contesta a acusação, sem, no entanto, assumir a culpa - plea of nolo contendere - ou declarar-se inocente - plea of not guilty. No silêncio do acusado, há de se entender que ele se declarou inocente.

O plea bargaining pode ocorrer, de fato, antes do início do julgamento, revestindo-se de um processo de negociação entre acusação e defesa do réu, que deságua na guilty plea ou no plea of nolo contedere, instrumentos do Direito americano já supramencionados.

Sendo assim, durante o processo do plea bargaining, pode propor o Estado uma relativização das acusações ou uma abreviação das sanções em troca de uma confissão de culpa que pode ser acompanhada da denunciação de esquemas criminosos dos quais o réu faz parte, fatores que serão sempre levados em consideração na realização da negociação. Há, nesse caso, uma renúncia aos direitos que o réu teria caso decidisse ir a julgamento. Logo, em audiência posterior ao acordo, o acusado deve manifestar sua decisão de aceitação do acordo perante um magistrado, e este último irá adverti-lo sobre a citada renúncia de direitos. O nolo contendere possui os mesmos efeitos na seara penal do que o guilty plea, diferenciando-se apenas pelo fato de que este serve para efeitos de responsabilização civil e aquele não (CAMPOS, 2012).

Em verdade, o plea bargaining é visto como um procedimento negocial entabulado entre a acusação e a defesa, resultando num acordo quanto à pena a ser imposta ao acusado. Trata-se de um verdadeiro pacto, regido pelos princípios contratuais (SALTZBURG; CAPRA, 1996).

\section{CARACTERÍSTICAS DA LEI E JURISPRUDÊNCIA BRASILEIRAS}

As críticas doutrinárias acerca do déficit legislativo juntamente com a necessidade de que uma lei regulamentasse o procedimento de realização da colaboração premiada deu origem a uma seção destinada ao mencionado instituto na Lei no 12.850/2013, conhecida como Lei de Organização Criminosa.

Diferentemente das leis anteriores, que somente traziam os direitos materiais dos colaboradores, a Lei no 12.850/2013 apresentou um desenvolvimento legislativo considerável no tocante à matéria, trazendo medidas de proteção ao colaborador e a forma de aplicação de tais medidas em 3 artigos, 16 incisos e 19 parágrafos.

As novidades foram bem acolhidas pelo sistema jurídico brasileiro. $\mathrm{O}$ artigo 5 o da Lei $\mathrm{n}$ - 12.850/2013 traz uma série de direitos que não estão diretamente ligados com o prêmio da colaboração. Trata-se do equivalente ao momento tutório na colaboração italiana, ou seja, são as medidas que garantirão a segurança do colaborador. É importante lembrar que, embora a Lei no 12.850/2013 tenha inovado a respeito da matéria de proteção do réu colaborador, ela não foi pioneira nessa matéria, dado que a própria Lei no 9.807/1999 fazia menção a algumas medidas deste tipo em seu texto.

\subsection{Direitos tutórios}

É importante reconhecer que a Lei no 9.807/1999 apresenta direitos tutórios ao colaborador, como a separação dos demais presos - caso se encontre nesta condição - e até mesmo a possibilidade de alteração do nome do colaborador e de seu cônjuge ou companheiro, ascendente, descendente e dependentes que tenham convivência habitual com o colaborador, conforme o artigo 9o da citada Lei. Tal preocupação é reforçada pelo inciso II do citado artigo $5^{\circ}$ da Lei de Organização Criminosa que afirma a proteção do nome, qualificação e imagem do colaborador ainda que não se chegue ao extremo da necessidade de mudá-lo.

Os incisos III e IV do mesmo dispositivo descrevem o tratamento do colaborador em juízo, estabelecendo o seu isolamento de demais coautores e partícipes. Interessa mencionar que tal isolamento, tanto em juízo, quanto penitenciário, além de ser uma medida de proteção do colaborador, é uma maneira de evitar 


\section{Direito \\ Debate}

COLABORAÇÃO PREMIADA: APORTES TEÓRICOS E JURISPRUDENCIAIS, O CASO DO BRASIL E INSERÇÕES NO DIREITO COMPARADO Fernando Soares Gomes - Ian Bernar Santos Barroso - Leandro Luciano Silva Ravnjak

que este, em conjunto com outros colaboradores, manipule as investigações, o que tornaria a utilização do instrumento inviável.

Posteriormente, os incisos $\mathrm{V}$ e VII, ainda do mesmo artigo, remetem, respectivamente, ao sigilo quanto à identidade do colaborador e ao direito de cumprimento da pena em estabelecimento diverso dos demais envolvidos. Nota-se, portanto, que, em que pese o caput do artigo 50 da Lei $n=12.850 / 2013$ estabeleça dizeres sobre os "direitos do colaborador", esses direitos são somente tutórios, sem que correspondam, de fato, ao principal benefício material do colaborador.

Nesse sentido, é importante destacar que a garantia de direitos tutórios ao colaborador, incorporados pela Lei $\mathrm{n}$ - 12.850/2013 ao Direito brasileiro, representa uma grande evolução desta ferramenta investigativa. É que a colaboração premiada, sem a garantia de proteção, pode representar um risco grande ao colaborador. Pessoas da alta cúpula de uma organização criminosa não realizarão delação premiada se souberem que correm o risco vida. Por outro lado, uma vez alterado seu nome e oferecido cumprimento de pena em estabelecimento diverso, torna-se razoável colaborar com o Estado. A existência de direitos tutórios no processo de colaboração premiada torna o instrumento investigativo mais efetivo, útil e adequado aos princípios da Constituição Federal.

\subsection{Dispersão legislativa}

Um dos aspectos que dificultam o uso a colaboração premiada no Brasil é a sua dispersão legislativa. Isso se deve ao fato de que o citado mecanismo foi introduzido de forma esparsa no ordenamento brasileiro, desenvolvendo-se de forma sucessiva, desde a Lei no 8.072/1990, conhecida como Lei de Crimes Hediondos, perpassando pela Lei $n$ o 9.807/1999, que redigiu o §4으 do artigo 159 do Código Penal, até a Lei no 12.850/2013 que, conforme já dito, enriqueceu seu aspecto processual.

A referida dispersão é percebida na própria repetição do conteúdo de diversos dispositivos legais referentes à política de colaboração. Note-se o exemplo: A Lei no 8.072/1990 diz no parágrafo único do artigo 80: "O participante e o associado que denunciar à autoridade o bando ou quadrilha, possibilitando seu desmantelamento, terá a pena reduzida de um a dois terços".

Por sua vez, a Lei no 9.807/1999, estabelece em seus artigos 13 e 14:

Art. 13. Poderá o juiz, de ofício ou a requerimento das partes, conceder o perdão judicial e a consequente extinção da punibilidade ao acusado que, sendo primário, tenha colaborado efetiva e voluntariamente com a investigação e o processo criminal, desde que dessa colaboração tenha resultado:

I - a identificação dos demais coautores ou partícipes da ação criminosa;

II - a localização da vítima com a sua integridade física preservada;

III - a recuperação total ou parcial do produto do crime.

Parágrafo único. A concessão do perdão judicial levará em conta a personalidade do beneficiado e a natureza, circunstâncias, gravidade e repercussão social do fato criminoso.

Art. 14. $\mathrm{O}$ indiciado ou acusado que colaborar voluntariamente com a investigação policial e o processo criminal na identificação dos demais coautores ou partícipes do crime, na localização da vítima com vida e na recuperação total ou parcial do produto do crime, no caso de condenação, terá pena reduzida de um a dois terços.

É evidente a evolução ocorrida entre os dois dispositivos legais. É mais perceptível o fato de que o segundo dispositivo legal abarca o primeiro. Dessa forma, restou cristalino que a colaboração premiada possui conceitos incompletos e desatualizados.

Analisando do ponto de vista da técnica legislativa, fica claro que, a cada dispositivo novo lançado sobre Direito Premial, um antecessor deveria ser revogado de forma expressa. Desse modo, além de evitar uma repetição desnecessária da lei e uma confusão no mundo jurídico, evita-se uma distorção ao princípio da isonomia. Afinal, pode ocorrer que determinado crime seja abarcado por um "prêmio" melhor do que outro. Não 
bastasse, o processo interpretativo da colaboração premiada fica prejudicado, principalmente o método de hermenêutica lógico-sistemático. ${ }^{8}$

Nesse sentido, afirma José Afonso da Silva (2016, p. 217-218): “[...] [tanto] a doutrina como a jurisprudência já firmaram, há muito, a orientação de que a igualdade perante a lei tem o sentido que, no exterior, se dá à expressão igualdade na lei, ou seja: o princípio tem como destinatário tanto o legislador como os aplicadores da lei". Continua: "aliás, Francisco Campos, com razão, sustentara mesmo que o legislador é o destinatário principal do princípio, pois se ele pudesse criar normas distintivas de pessoas, coisas ou fatos, que devessem ser tratados com igualdade, o mandamento constitucional se tornaria inteiramente inútil.

Nesse viés, os ditames legislativos relativos à colaboração premiada devem, ao englobar uns aos outros, revogar-se de forma expressa, sob pena de trazer confusão ao Direito Premial brasileiro.

\subsection{Efeitos civis da colaboração premiada}

É sabido que, em determinadas ocasiões, o Direito Criminal influi na área cível. Exemplo disso é o campo da responsabilidade civil, no qual havendo o fato em que se origine ação cível e criminal, esta irá exercer influência sobre aquela, inclusive devendo haver na sentença penal o valor mínimo para a reparação do dano, valor este que pode ser majorado na seara cível.

Por conseguinte, uma das possibilidades postas pela colaboração premiada é o envolvimento de questões cíveis, principalmente acerca do ressarcimento, entre as cláusulas do contrato processual de colaboração premiada. Um aspecto que é verificado, contudo, é o fato de que as leis penais não mencionam essa questão entre as formas pelas quais deve haver a colaboração, o que, em tese, poderia ferir o princípio da legalidade estrita.

Não é razoável, entretanto, entender que a colaboração premiada pode ser restrita aos campos penais quando há um caráter patrimonial na prática do crime. Não seria proporcional, verbi gratia, que aquele que realiza um furto juntamente com organização criminosa se livrasse dos efeitos penais por fazer uma delação premiada e não ressarcisse o valor ou bem furtado à vítima. Trata-se de uma contradição impensável, não só no campo jurídico, mas igualmente com relação aos ideais de Justiça que devem ser nutridos em um regime democrático.

Por isso, com fundamento no dever de neminem laedere, a melhor solução é a de que a imposição do ressarcimento no acordo de colaboração premiada seja requisito obrigatório, não podendo o Ministério Público propor a sua dispensa, ainda que a vítima posteriormente possa se valer de ação civil para tal fim.

Não é preciso que se espere que a sentença penal estabeleça o valor mínimo para a reparação civil se o colaborador, como rege a própria denominação, se faz presente para colaborar. Uno que é o Direito, a existência de cláusulas de reparação do dano no acordo de colaboração premiada é plenamente razoável, de forma que, inclusive, após a homologação judicial do acordo, este pode ser usado como título executivo.

\subsection{Pontuações jurisprudenciais}

É importante, ainda, considerar as decisões proferidas pelos tribunais brasileiros com relação à colaboração premiada. O Supremo Tribunal Federal já fez importantes considerações acerca da utilização do instituto, as quais ajudam a compreender e interpretar os seus dispositivos.

Nesse sentido, deve-se analisar o acesso da colaboração premiada pelo defensor do delatado em processo de colaboração. A esse respeito, o artigo 7으, §2으 da Lei $n=12.850 / 2013^{9}$ assegura ao defensor, o amplo acesso a elementos de prova que se liguem ao direito de defesa. Além disso, a súmula vinculante no 14 do STF e o artigo 7으, XIV da Lei no 8.906/1994 (Estatuto da OAB) reforçam esse acesso. A jurisprudência, todavia, em

\footnotetext{
8 "É preciso, pois, interpretar as leis segundo seus valores linguísticos, mas sempre situando-as no conjunto do sistema. Esse trabalho de compreensão de um preceito em sua correlação com todos os que com ele se articulam logicamente, denomina-se interpretação lógicosistemática" (REALE, 2002).

9 "O acesso aos autos será restrito ao juiz, ao Ministério Público e ao delegado de Polícia, como forma de garantir o êxito das investigações, assegurando-se ao defensor, no interesse do representado, amplo acesso aos elementos de prova que digam respeito ao exercício do direito de defesa, devidamente precedido de autorização judicial, ressalvados os referentes às diligências em andamento."
} 
regra, tem decidido acerca da impossibilidade de acesso às declarações de colaboração premiada por terceiros quando na fase de Inquérito Policial. Isso porque, como instituto processual que é, para os tribunais superiores e para a própria Lei $n=12.850 / 2013,{ }^{10}$ a colaboração premiada não é considerada uma prova, mas apenas meio de obtenção desta, de forma que o acesso a estas declarações, ainda que por parte de defensor de sujeito citado em delação premiada, poderia frustrar diligências para a obtenção de provas. ${ }^{11}$ Ademais, entende-se, conforme decidido pelo STJ no HC 67.49, pela relativização do §3으 do artigo 70 da Lei no 12.850/2013, sendo possível ao magistrado denegar o acesso de terceiros ao termo de colaboração premiada até mesmo após a denúncia, desde que haja a devida fundamentação.

No HC 127.483, o STF fez importantes considerações acerca do instituto. A primeira delas é acerca da natureza da colaboração. Deixou assente o Tribunal que a colaboração premiada é um negócio jurídico processual, justificando-se por ser tratado como meio de obtenção de prova pela lei, de forma que a cooperação se faz, primordialmente, para a investigação e para o processo criminal.

Outra questão é que o Supremo entendeu que, no que se refere ao inciso I do artigo 4ㅇ da Lei no 12.850/2013, a personalidade não é requisito de validade, mas apenas um vetor a ser considerado no processo.

Por fim, ainda no citado Habeas Corpus, o STF decidiu pela impossibilidade de impugnação da colaboração por coautores ou partícipes do colaborador. Isso por que, conforme entendimento, a colaboração é um negócio jurídico processual personalíssimo.

É importante salientar que os tribunais têm sido rigorosos quanto ao cumprimento dos requisitos objetivos da colaboração premiada. Significa afirmar aqueles que não colaboram de forma efetiva com as investigações não farão jus ao benefício principal. $O$ acordo realizado com a Justiça Criminal não pode admitir meias-verdades ou informações duvidosas. Afinal, se por um lado é certo que está em jogo as liberdades de um indivíduo, do outro está a efetividade da Justiça Criminal e da pacificação social, com as quais não se pode admitir a leviandade ou a omissão, sob pena de o benefício obtido se dilacerar.

\subsection{Alterações legais promovidas na Lei no 12.850/2013 - quanto à colaboração premiada - pelo \\ "Pacote Anticrime" (Lei № 13.964/2019)}

Além da inclusão mencionada na parte final da seção de número 3 deste trabalho (Natureza Jurídica da Colaboração Premiada), a Lei no 13.964/2019 promoveu outras relevantes alterações na Lei de Organização Criminosa, especialmente quanto ao mecanismo da colaboração premiada, dispostas no artigo 14 da Lei no 13.964/2019.

O Pacote Anticrime operou uma significativa alteração do procedimento investigativo. A partir desse texto legal, entre outras mudanças: I) manteve-se a audiência prevista no §7으, artigo 4으 da redação anterior, ${ }^{12}$ ampliando, contudo, "os aspectos que devem ser levados em consideração, pelo juiz, quando da homologa-

\footnotetext{
${ }_{10}$ Lei no 12.850/2013. Art. 3 - "Art. 3 Em qualquer fase da persecução penal, serão permitidos, sem prejuízo de outros já previstos em lei, os seguintes meios de obtenção da prova: I - colaboração premiada". Grifo.

${ }^{11}$ É importante entender que o assunto não é pacífico na jurisprudência ainda. Mais de uma vez, contudo, tem se decidido pela impossibilidade do acesso às declarações dadas em delação premiada em fase de inquérito, posto que o §2으 do artigo 7으 da Lei n으 $12.850 / 2013$ garante o acesso aos elementos de prova, e não aos meios de produção destas, como é o caso da colaboração premiada. Interessante, assim, é a colocação do Min. do STJ Felix Fischer no HC 67.493 em que ele afirma que: "De fato, dispõe o §3으 do art. 70 da Lei $\mathrm{n}$ - 12.850/2013 que 'O acordo de colaboração premiada deixa de ser sigiloso assim que recebida a denúncia, observando o disposto no art. 5', o qual, por sua vez, explicita os direitos do colaborador. Trata-se de uma regra de caráter não absoluto, haja vista a própria exceção da publicidade no que diz respeito aos direitos do colaborador previstos no art. 5o do mesmo diploma legal. Não obstante, ainda que não disposto expressamente no dispositivo legal mencionado, tenho que deve ser ressalvado o acesso ao acordo de colaboração no que pertine a outras situações que não estejam diretamente ligadas à ação penal em que o recorrente figura como réu, que versem sobre investigações ainda em curso, o que parece ser o caso. Isto porque, a meu ver, deve ser realizado um juízo de ponderação entre o direito ao contraditório e à ampla defesa, por um lado, e a necessidade de proteção das informações relativas a investigações ainda em curso, de outro".

$12 \S 70$ "Realizado o acordo na forma do $\S 6$ \% , o respectivo termo, acompanhado das declarações do colaborador e de cópia da investigação, será remetido ao juiz para homologação, o qual deverá verificar sua regularidade, legalidade e voluntariedade, podendo para este fim, sigilosamente, ouvir o colaborador, na presença de seu defensor".
} 
ção; ${ }^{13 "}$ II) admite-se "a ação de agentes de polícia infiltrados virtuais [...] com o fim de investigar os crimes previstos nessa Lei", o que se considera relevante para a investigação de crimes cibernéticos, por exemplo; III) possibilita-se a recusa da homologação pelo magistrado, momento no qual deverá devolver a proposta às partes para as adequações necessárias e IV) exige-se que "o registro das tratativas e dos atos de colaboração seja feito pelos meios ou recursos de gravação magnética, estenotipia, digital ou técnica similar, inclusive audiovisual, destinados a obter maior fidelidade das informações"(MELO; BROETO, 2019; FIGUEIREDO, 2020; BRASIL, 2019).

Algumas das alterações promovidas pela Lei № 13.964/2019 representam, no entanto, apenas "inovações simbólicas", eis que não alteram "substancialmente o que já era disciplinado". É o que ocorre, por exemplo, com a inclusão do artigo 3 ํ--B, que positiva a seguinte redação:

Art. 3--B. O recebimento da proposta para formalização de acordo de colaboração demarca o início das negociações e constitui também marco de confidencialidade, configurando violação de sigilo e quebra da confiança e da boa-fé a divulgação de tais tratativas iniciais ou de documento que as formalize, até o levantamento de sigilo por decisão judicial (Grifo).

Isso porque "a práxis já impunha a assinatura de termo de confidencialidade entre autoridades públicas, colaborador e advogado, quando da celebração de acordo de colaboração premiada", consoante afirmam (MELO; BROETO, 2019), contudo o "vazamento de informações tão logo se assinava o acordo era regra". Desse modo, "não se verifica nenhum preceito secundário no artigo 3--B, mas apenas 'um tipo remetido', em relação aos agentes públicos, e uma possível quebra da boa-fé, a redundar no âmbito de eficácia do acordo".

Por outro lado, o mencionado artigo 3--B, incluído na Lei no 12.850/2013, ultrapassa o posicionamento simbólico, ao lecionar, em seu primeiro parágrafo, que: "A proposta de acordo de colaboração premiada poderá ser sumariamente indeferida, com a devida justificativa, cientificando-se o interessado", haja vista que se impõe "uma espécie de motivação para o indeferimento sumário da proposta de acordo de colaboração premiada". Melo e Broeto, (2019) ponderam que "num Estado Democrático de Direito, como é o caso do Brasil, o Parquet deve explicitar as razões pelas quais não entende viável a formalização de acordo premiada", em decorrência, sobretudo, da própria dicção prescrita pela CRFB/88. ${ }^{14}$

Existem, contudo, dispositivos no mencionado artigo 14 da Lei no 13.964/2019, inseridos no texto da Lei no 12.850/2013, que promovem verdadeiras inovações ao conteúdo do tema em debate. É o caso do artigo 3ㅇ-C, §§3ㅇ e 4으, que restringe o "objeto da investigação, nos seguintes termos:

§3o No acordo de colaboração premiada, o colaborador deve narrar todos os fatos ilícitos para os quais concorreu e que tenham relação direta com os fatos investigados. §40 Incumbe à defesa instruir a proposta de colaboração e os anexos com os fatos adequadamente descritos, com todas as suas circunstâncias, indicando as provas e os elementos de corroboração (Grifo).

Melo e Broeto (2019) pontuam que "que tal previsão atende às críticas da doutrina, que via como um verdadeiro abuso ter o colaborador que, num determinado procedimento investigativo, falar sobre fatos totalmente alheios à investigação". Cabe destacar a argumentação dos referidos autores, em clara exemplificação da aludida inserção legal:

\footnotetext{
${ }^{13}$ São eles, na forma do $\S 7$, do artigo 4ㅇ: "I - regularidade e legalidade; II - adequação dos benefícios pactuados àqueles previstos no caput e nos $\S \S 40$ e 5o deste artigo, sendo nulas as cláusulas que violem o critério de definição do regime inicial de cumprimento de pena do artigo 33 do Decreto-Lei no 2.848, de 7 de dezembro de 1940 (Código Penal), as regras de cada um dos regimes previstos no Código Penal e na Lei no 7.210, de 11 de julho de 1984 (Lei de Execução Penal) e os requisitos de progressão de regime não abrangidos pelo §5을 deste artigo; III - adequação dos resultados da colaboração aos resultados mínimos exigidos nos incisos I, II, III, IV e V do caput deste artigo; IV - voluntariedade da manifestação de vontade, especialmente nos casos em que o colaborador está ou esteve sob efeito de medidas cautelares".

${ }^{14}$ Consoante preleciona o artigo $129, \S 4$ 으, da CRFB/88, ao Ministério Público se aplica, no que couber, o artigo 93 da CRFB/88. Por sua vez, o inciso IX do artigo 93 da Constituição Federal impõe que "todos os julgamentos dos órgãos do poder Judiciário serão públicos, e fundamentadas todas as decisões, sob pena de nulidade, podendo a lei limitar a presença, em determinados atos, às próprias partes e a seus advogados, ou somente a estes, em casos nos quais a preservação do direito à intimidade do interessado no sigilo não prejudique o interesse público à informação".
} 
Doravante, se há investigação, por exemplo, sobre crimes de corrupção praticados no âmbito do poder Legislativo, em período determinado, deverá o colaborador esclarecer tudo o que sabe sobre esses fatos, não sendo obrigado a declarar nada que não esteja, geográfica e/ou temporalmente, compreendido no específico âmbito das investigações.

Em mesma vertente encontra-se a previsão de rescisão do acordo colaborativo "em caso de omissão dolosa sobre os fatos objeto da colaboração" ( $\$ 17$ do artigo 4ํ), bem como na hipótese de "envolvimento [do colaborador] em conduta ilícita relacionada ao objeto da colaboração" (\$18 do artigo 4ํ). Além disso, elenca-se a vedação ao magistrado de decidir pela publicidade do acordo de colaboração premiada e dos depoimentos do colaborador em qualquer hipótese ( 33 음 do artigo 7으).

Por fim, o que se nota da redação em foco é o atendimento de consistentes coros doutrinários e jurisprudenciais, consoante asseveram Melo e Broeto (2019), produzidos após a verificação de lacunas e inconsistências legais que, por sua vez, colocavam "colaboradores e delatados em situação de fragilidade e insegurança jurídica". É válido frisar, nesse sentido, que a argumentação aqui empreendida e ratificada deu-se com base na leitura, conforme já dito, dos elementos normativos positivados pelo artigo 14 da Lei no 13.964/2019, que se referem especificadamente ao conteúdo da colaboração premiada.

\section{AS CORRENTES UTILITARISTA E FUNDAMENTALISTA}

A colaboração premiada constitui-se como uma ferramenta de investigação criminal que influencia diversos debates dentro da doutrina brasileira e internacional. Um dos principais debates diz respeito à constitucionalidade ou não do instrumento. São duas as correntes que discutem a compatibilidade da colaboração premiada com a Constituição Federal: a utilitarista e a fundamentalista.

A concepção utilitarista da colaboração premiada é aquela que se apoia sobre uma abordagem pragmática, ou seja, o entendimento de que esse instituto torna mais prática e realista as investigações criminais. Essa nomenclatura pode ser encontrada na obra de Tasse (2006), na qual ele afirma que a concepção utilitarista é "verdadeiro afastamento de alguns setores do poder Judiciário da pregação dogmática do Direito Penal e dos aspectos garantistas que esta traz em seu bojo, optando-se por uma racionalização utilitarista do direito penal". Tal concepção entende a colaboração premiada como uma importante arma no combate e repressão à criminalidade, sobretudo a organizada, visto que ela pode aproximar o Estado da verdade real, princípio inerente ao processo.

Dessa maneira, relativizam-se critérios de ordem ética e moral para se primar pela busca da verdade real e pela eficiência do sistema.

A construção de um aspecto conceitual para a corrente fundamentalista da colaboração premiada perpassa por teorias como a garantista. Elaborada pelo professor Luigi Ferrajoli, tal doutrina entende que o garantismo designa um modelo normativo de Direito: precisamente, no que diz respeito ao Direito Penal, o modelo de 'estrita legalidade', defendendo "uma teoria jurídica da 'validade' e da 'efetividade' como categorias distintas não só entre si, mas, também, pela 'existência' ou 'vigor' das normas" (FERRAJOLI, 2010).

Nesse sentido, a concepção fundamentalista é a aquela que defende que a colaboração premiada contraria determinadas garantias fundamentais previstas na Constituição Federal, tais como a ampla defesa, o contraditório e o direito a não autoincriminação. Tal concepção opta pela teoria garantista de forma próxima ao ortodoxo, chegando alguns autores a sustentar a inconstitucionalidade absoluta da colaboração premiada no Direito brasileiro.

Alimentam o debate da questão supramencionada os princípios constitucionais da presunção de inocência e do direito do preso de permanecer em silêncio sem que isso pese contra si, ambos previstos respectivamente no artigo 5o, incisos LVII e LXII da Constituição Federal e, também, uma importante garantia fundamental, que deriva de tais princípios constitucionais: o direito de "não produzir provas contra si", que encontra respaldo na Convenção de Direitos Humanos de 1969 (Pacto de San José da Costa Rica), em seu artigo 8으, que garante a toda pessoa acusada de um delito o "direito de não ser obrigada a depor contra si mesma, nem a confessar-se culpada". 
A concepção fundamentalista é aquela que leva os princípios constitucionais à última fase, observando gramaticalmente todos os dispositivos constitucionais. Trata-se de uma corrente que coloca os princípios éticos e valores morais à frente da própria efetividade investigativa do Estado.

Em verdade, as duas teorias defendem o sopesamento dos mesmos pontos. O que aloca um posicionamento como utilitarista ou fundamentalista é a defesa de uma persecução mais efetiva e facilitada do Estado ou de uma valorização da ética e dos valores morais, bem como uma interpretação gramatical e rígida dos princípios constitucionais.

\section{VALIDADE, ADEQUAÇÃO E USO DA COLABORAÇÃO PREMIADA NO DIREITO BRASILEIRO}

Realizada toda a exposição dos aspectos teóricos e doutrinários acerca da colaboração premiada no Brasil e apontamentos em legislações estrangeiras, chega-se à análise final do trabalho. A legitimidade da colaboração premiada dentro do cenário jurídico brasileiro é motivo de muitas discussões, as quais, por vezes apontam sua inconstitucionalidade, como é o caso das correntes fundamentalistas, previamente analisadas, a invalidade das provas obtidas por este meio ou até mesmo a ineficiência do instrumento nas investigações.

\subsection{Legitimidade constitucional}

Uma vez não limitada e regulamentada, a colaboração premiada pode, de fato, tornar-se um instrumento de violação de direitos fundamentais.

A análise da constitucionalidade do instrumento deve passar não apenas pelo confronto entre a colaboração premiada e cada dispositivo constitucional individualmente, mas também pela adequação da ferramenta ao sistema constitucional brasileiro, como uma espécie de hermenêutica lógico-sistemática.

O fato é que a Lei Federal no 12.850/2013 trouxe um novo paradigma ao mecanismo em análise. A legislação sobre os aspectos processuais e procedimentais da colaboração premiada até então era quase inexistente, o que causava um grande prejuízo ao instrumento, uma vez que a própria natureza deste é a de meio de obtenção de provas na persecução criminal, ou seja, uma natureza processual. Assim, em conformidade com o princípio da legalidade estrita, a Lei no 12.850/2013 trouxe para o Direito brasileiro acepções processuais sobre a colaboração premiada, tais como aquelas presentes nos parágrafos do artigo 4으, como a possibilidade de o juiz adequar o acordo ou não homologá-lo, quais as partes realizam o acordo e a proibição de sentença com base somente em depoimento prestado por agente colaborador.

Os já abordados direitos tutórios do colaborador, os quais estão presentes na lei italiana e foram trazidos ao Brasil com a supracitada Lei Federal, aferem uma humanização ao instituto, fazendo com que o agente colaborador tenha espaço para favorecer efetivamente as investigações sem que tenha de temer por sua vida ou pela de seus familiares.

Outra questão é que se abordou no texto o exemplo de dois países em que a colaboração premiada está presente há muito. Trata-se de um instrumento utilizado com frequência, principalmente nos Estados Unidos. A discricionariedade do órgão de acusação facilita o acordo de colaboração premiada, uma vez que, independentemente da lei, pode o promotor de Justiça propor a ausência de ação penal contra o agente colaborador.

É preciso salientar que a colaboração premiada mostra-se, dentro do panorama jurídico brasileiro, um instrumento oficial de combate à criminalidade e que, embora possa relativizar direitos constitucionais do agente colaborador, este não está obrigado a colaborar, podendo se submeter ao resultado das investigações na forma ordinária.

Questiona a doutrina fundamentalista a violação de direitos como o direito ao silêncio, a ampla defesa e o contraditório. Como já referido, tais direitos fundamentais podem ser relativizados pelo seu titular, desde que este esteja com a vontade livre e desembaraçada. O réu tem o direito ao silêncio, mas pode confessar, se assim o desejar. Tem direito à ampla defesa e contraditório, mas pode optar por não se defender, sendo revel. O mesmo ocorre com a colaboração premiada: pode optar por abrir mão de sua defesa e de seu direito ao silêncio, garantindo vantagem material e processual.

A colaboração premiada, portanto, consolida-se constitucionalmente pela existência de regras processuais que limitam a sua utilização à garantia de determinadas proteções ao agente colaborador e aos terceiros 
atingidos pelo instrumento, seja pelos direitos tutórios, seja por outras limitações, a exemplo da impossibilidade de condenação somente com base em declarações de um agente colaborador.

\subsection{Validade utilitária}

Superada a validade constitucional, passa-se ao valor utilitário da colaboração premiada. O que se pretende investigar é se o instrumento em estudo é realmente eficaz e se, de fato, facilita as investigações. Nesse sentido, temos que o viés histórico é o mais recomendado para perceber se a colaboração premiada é um instrumento efetivo ou não.

O surgimento da colaboração premiada dá-se em meio a uma necessidade eminente. O Estado italiano precisava desenvolver uma forma de acessar as organizações mafiosas que haviam se estruturado muito bem, havendo uma organização hierárquica muito consolidada. Naqueles episódios, o instituto da colaboração premiada amenizou o problema das máfias, embora não as tenha erradicado. É importante lembrar que o instrumento não foi a única solução, mas atuou aliado a uma maior rigidez da lei penal italiana, fazendo com que os agentes colaboradores se dissociassem dos grupos criminosos. Nota-se que a Lei $n=12.850 / 2013$, ao trazer em seu artigo 211 um novo tipo penal com a pena de três a oito anos apresenta uma solução semelhante, uma vez que traz a colaboração premiada e outros meios de obtenção de provas, como a ação controlada e a interceptação telefônica.

Outra questão abordada é a presença da colaboração premiada na História brasileira. Chama-se a atenção para o fato de que a esta esteve presente em momentos importantes da História brasileira. Nesses episódios, o instrumento mostrou-se efetivo para as leis da época, ainda que estas não fossem condizentes com a realidade constitucional atual.

O instrumento foi bem-sucedido, por exemplo, nos episódios da Inconfidência Mineira e da Conjuração Baiana, nas quais um dos participantes do movimento de rebelião delatou a existência deste, observando-se que, em ambos os casos, deu-se fim aos movimentos. Não se discute a justiça ou não de tais movimentos. $O$ fato é que, em ambos os episódios, o Estado conseguiu um acesso a informações que pelos meios tradicionais de investigação da época não teria conseguido, acessando assim os grupos rebeldes - considerados criminosos à época - e findando tais movimentos.

Atualmente, a lei brasileira apresenta uma variedade de formas de realizar-se colaboração premiada que vão além da delação. A diversificação das formas de colaborar é um aspecto positivo que a lei brasileira incluiu no instrumento. É importante que a colaboração premiada não se limite à delação para que as autoridades tenham formas de, além de descobrir as verdades fáticas, impedir a concretização de crimes ou obter produtos destes, como ocorre respectivamente na colaboração prevista no §40 do artigo 159 do Código Penal ${ }^{15}$ e no inciso IV do artigo 4 o da Lei no $12.850 / 2013 .{ }^{16}$ É um aspecto meritório da lei brasileira.

Por outro lado, é importante frisar que a dispersão legislativa existente no cenário jurídico brasileiro pode atrapalhar a aplicação da colaboração premiada. O texto, que deveria ter sido revogado expressamente, ${ }^{17}$ continua presente no ordenamento brasileiro, podendo causar problemas de hermenêutica e até mesmo de isonomia.

Essa pequena desorganização legislativa, contudo, por assim dizer, não é suficiente para tornar a colaboração premiada ineficiente no cenário jurídico brasileiro. $O$ fato é que, historicamente, o instrumento já se mostra eficaz para que o Estado consiga informações e acesso que tradicionalmente não conseguiria.

Atualmente, mais bem desenvolvida, a colaboração premiada ainda se mostra uma fonte de informações eficaz. É um instituto adequado aos padrões investigativos brasileiros, que traz uma gama de possibili-

\footnotetext{
${ }^{15}$ Código Penal. Artigo 159, §4ㅇ. "Se o crime é cometido em concurso, o concorrente que o denunciar à autoridade, facilitando a libertação do sequestrado, terá sua pena reduzida de um a dois terços" (Grifo)

${ }^{16}$ Lei $12.850 / 2013$. Artigo 4ㅇ, IV. "[...] a recuperação total ou parcial do produto ou do proveito das infrações penais praticadas pela organização criminosa".

${ }^{17}$ Conforme já afirmado, embora não tenham sido revogados expressamente, considera-se que as disposições sobre a colaboração premiada nas leis anteriores à Lei no 12.850/2013, à exceção do Código Penal, que traz uma colaboração específica para o tipo penal, estão tacitamente revogados.
} 
dades tanto para o agente colaborador, que tem novas formas de colaborar diferentes da delação premiada, quanto para o Estado, que tem novas formas de acesso a informações, produtos do crime e até mesmo formas de evitar a consumação de um tipo penal.

\subsection{Validade probatória}

Por fim, discute-se o quesito validade probatória da colaboração premiada como meio de obtenção de provas que é. As provas obtidas por meio da colaboração premiada devem ser válidas, sob pena de se tornar o instituto inútil. Assim, analisar se tais provas não possuem algum tipo de vício devido ao meio pelo qual foram obtidas é também essencial para verificar a validade da colaboração premiada no Direito brasileiro.

Para essa reflexão é necessário avaliar as regras processuais da colaboração premiada. É preciso verificar se a forma como essas regras são apresentadas não ocasiona algum risco à vontade do agente colaborador, que deve ser livre e desembaraçada.

Como já foi mencionado, o modelo italiano somente atribui valor probatório à colaboração premiada nos casos em que esta esteja acompanhada de outras provas que confirmem o seu teor. Assim, este modelo estabelece um percurso lógico obrigatório para realização da colaboração premiada que garante a validação de suas provas, constituindo-se em três fases:

[...] (a) Em primeiro lugar, deve-se verificar a credibilidade do declarante através de dados como sua personalidade, seu passado, sua relação com os acusados, o motivo da sua colaboração; (b) posteriormente, analisa-se a confiabilidade intrínseca ou genérica da declaração, auferida da sua seriedade, precisão, coerência, constância e espontaneidade; (c) por último, valora-se a existência e consistência das declarações com o confronto das demais provas, ou seja, atesta-se a confiabilidade extrínseca ou específica da declaração (BITTAR, 2011).

Com a Lei no 12.850/2013, o legislador brasileiro optou por solução semelhante à supracitada. Destacam-se os $\S \S 1$ 으 e 16 do artigo 40 da Lei no 12.850/2013 que afirma que a concessão do benefício deve levar em conta a personalidade do colaborador, a natureza, as circunstâncias, a gravidade e a repercussão social do fato, além da eficácia da colaboração e que não é possível condenação somente com base em declarações de um agente colaborador.

A averiguação da confiabilidade das declarações de um agente colaborador, citada no §1 do artigo 4은 da Lei no 12.850/2013, é reforçada pelo artigo 197 do Código de Processo Penal, ${ }^{18}$ que embora fale sobre confissão, aplica-se à colaboração premiada de forma análoga, uma vez que, como já foi afirmado, os dois institutos apresentam aspectos semelhantes, e, no caso em questão, não há nenhum prejuízo ao réu.

Outra questão a ser discutida, embora a Lei no 12.850/2013 não faça disposição a respeito, é a revogação da colaboração premiada. O ideal é que haja no próprio acordo disposição a esse respeito, afirmando que o seu descumprimento resulta na revogação do acordo. Inexistindo, contudo, cláusula neste teor, deve-se verificar se há validade das provas obtidas.

Diferencia-se as consequências caso seja o acordo revogado ou anulado. Ressalta-se, para este assunto, a teoria dos frutos da árvore envenenada (fruits of the poisonous tree). É lógico pensar que havendo vícios no instrumento de obtenção de provas, esse vício contaminará todas aquelas obtidas. Se é fato que as provas obtidas por uma invasão ilegal a domicílio são viciadas, tendo em vista que o meio utilizado foi inválido, aquelas provas obtidas por uma colaboração realizada em que não houve uma vontade livre e desembaraçada também serão. Nesse sentido, anulado o acordo de colaboração premiada, em regra deve-se desentranhar dos autos as provas obtidas por aquele meio.

Diferente é o caso de revogação do acordo de colaboração premiada. Enquanto na anulação há uma causa desde o início que torna o acordo viciado, nessa o colaborador pratica ato incompatível com a colaboração prestada. É o caso, por exemplo, daquele que realiza colaboração premiada e, posteriormente, descobre-

\footnotetext{
${ }_{18}$ Código de Processo Penal. Artigo 197. “O valor da confissão se aferirá pelos critérios adotados para os outros elementos de prova, e para a sua apreciação o juiz deverá confrontá-la com as demais provas do processo, verificando se entre ela e estas existe compatibilidade ou concordância".
} 


\section{Direito \\ Debate}

COLABORAÇÃO PREMIADA: APORTES TEÓRICOS E JURISPRUDENCIAIS, O CASO DO BRASIL E INSERÇÕES NO DIREITO COMPARADO Fernando Soares Gomes - Ian Bernar Santos Barroso - Leandro Luciano Silva Ravnjak

-se ter ele ocultado, dolosamente, determinadas informações essenciais para a investigação; ou até mesmo daquele que delata uma organização criminosa e após volta a integrá-la ou outra organização.

Nos casos de revogação do benefício de colaboração premiada, as informações e as provas obtidas por meio deste instituto não estarão invalidadas, mas somente o benefício daquele que, em um momento anterior, havia colaborado com a Justiça Criminal.

Observa-se que a Lei № 12.850/2013 cercou a colaboração premiada de regramentos necessários para a sua adaptação ao ordenamento jurídico brasileiro. No caso da validade probatória, a lei em questão apresentou procedimentos que vão além dos direitos tutórios, ou seja, regras essencialmente procedimentais que buscam garantir que não há vício na vontade do agente colaborador. Consequentemente, as provas obtidas por processo de colaboração premiada, desde que obedecidas as regras da Lei $12.850 / 2013$, são plenamente válidas e não possuem, de forma originária, qualquer mácula em seu aspecto de validade.

\subsection{O uso e abuso da colaboração premiada na história recente brasileira e a Operação Lava Jato}

Conforme mencionado anteriormente, o instituto da colaboração premiada apareceu em diversos momentos da História do mundo e brasileira. Sobre esta última, ganhou destaque recente com episódios no curso da operação policial chamada de Lava Jato. Embora não seja o objetivo deste estudo analisar e julgar aplicações específicas do instituto no curso da operação, é certo que alguns aspectos gerais sobre a sua utilização são relevantes e merecem uma sucinta análise.

Nesse contexto, devem ser discutidos dois aspectos essenciais do instrumento: a sua eficácia para a investigação criminal e o respeito aos direitos dos colaboradores e às regras procedimentais do instituto.

Quanto ao primeiro ponto, não restam dúvidas de que fora satisfatoriamente atingido, embora os desdobramentos da citada operação ainda estejam ocorrendo na data de produção do presente texto. É dizer, a aplicação do instrumento surtiu efeitos positivos no âmbito das investigações criminais, permitindo se atingirem resultados que talvez não seriam alcançados sem o uso de tal ferramenta, que se mostrou, portanto, útil. Isso pode ser confirmado inicialmente com os resultados gerais da Operação Lava-Jato: Conforme noticiado em diversos meios, como no jornal G1.globo. Com $^{19}$ e Folha de São Paulo, ${ }^{20}$ a operação possibilitou a descoberta de relevantes fatos relacionados a empresários e políticos que teriam praticado crimes contra a Empresa Estatal Petróleo Brasileiro S.A.

Ademais, conforme o site Consultor Jurídico, ${ }^{21}$ entre os anos de 2015 e 2019 foram celebrados 37 acordos de colaboração premiada no âmbito da Lava Jato, o que, até então, havia possibilitado a recuperação de $\mathrm{R} \$ 945.000 .000,00$ (novecentos e quarenta e cinco milhões de reais) para os cofres públicos. Isso demonstra que o instrumento foi útil não somente na seara criminal, mas também cível.

Observando, contudo, a aplicação do instituto sob o panorama dos direitos dos investigados e da observância das normas procedimentais que o regem, nota-se a presença de diversas falhas.

Inicialmente, vê-se que a exposição midiática excessiva da operação é algo que, por si só, contraria as normas que regem o instituto. Ora, o procedimento de colaboração, pela sua natureza, deve ser realizado da forma mais reservada possível, a fim de preservar a intimidade do colaborador, que, afinal, pode sofrer diversos riscos em razão das informações que repassa à investigação.

Nesse sentido, é preciso ver que a Lei Federal no 12.850/2013 estabelece que são direitos do colaborador "ter nome, qualificação, imagem e demais informações pessoais preservados" e "não ter sua identidade revelada pelos meios de comunicação, nem ser fotografado ou filmado, sem sua prévia autorização por escrito" (BRASIL, 2013). Ademais, o art. 3--B, acrescido pela recente reforma da Lei no 13.964/2019, é firme ao

\footnotetext{
$\overline{19}$ G1.GLOBO.COM. Operação Lava Jato. 2021. Disponível em: https://g1.globo.com/politica/operacao-lava-jato/. Acesso em: 5 jan. 2021.

${ }^{20}$ FOLHA DE SÃO PAULO. Folha explica: Operação Lava Jato. 2021. Disponível em: http://arte.folha.uol.com.br/poder/operacao-lava-jato/. Acesso em: 5 jan. 2021.

${ }^{21}$ CONSULTOR JURÍDICO. "Lava jato" no Rio já tem 37 acordos de delação premiada homologados. 2019. Disponível em: https://www.conjur. com.br/2019-ago-21/lava-jato-rio-37-acordos-delacao-premiada-homologados. Acesso em: 5 jan. 2021.
} 
vedar a divulgação de tratativas iniciais da colaboração premiada, o que configura violação de sigilo e quebra da confiança e da boa-fé.

Diferentemente do estabelecido, contudo, o que se vê é uma grande exposição midiática, na qual há divulgações até mesmo de colaborações ainda não celebradas, mas já especuladas, o que certamente viola os direitos tutórios do colaborador.

Por outro lado, vê-se que há indícios de que, por vezes, prisões cautelares tenham sido decretadas com o fito de coagir pessoas a realizarem colaborações premiadas. É o que se mostrou em alguns pareceres isolados do Ministério Público Federal, nos quais se teria afirmado que um dos elementos autorizativos da prisão preventiva seria a "importante função de convencer os infratores a colaborar com o desvendamento dos ilícitos penais". ${ }^{22}$ É dizer, pretendeu-se prender para coagir à colaboração.

Tal fato vai de encontro ao aspecto da voluntariedade e liberdade da colaboração e, fundamentalmente, afronta a presunção de não culpabilidade, contida no artigo 5ㅇ, inc. LVII, da CRFB/1988. Aliás, o artigo 4ํ, da Lei $n$ o 12.850/2013, em seu §7으, inc. IV, define que o acordo deve ser feito de forma voluntária, especialmente nos casos em que o colaborador está ou esteve sob efeito de medidas cautelares, enquanto o §16, inc. I, veda a decretação de medidas cautelares reais ou pessoais com fundamento apenas nas declarações do colaborador.

O que se vê, portanto, na história recente do Brasil e tomando por base a operação Lava Jato, é que, embora a colaboração premiada tenha grande eficácia, os órgãos investigatórios ainda precisam evoluir na aplicação do instituto quanto ao respeito a determinados direitos do colaborador, especialmente quanto à preservação da sua intimidade e quanto à voluntariedade do instituto. Afinal, o desrespeito a tais garantias pode levar à nulidade das provas obtidas e, consequentemente, ao desperdício de tempo e trabalho.

\section{CONSIDERAÇÕES FINAIS}

O surgimento de métodos e técnicas de investigação criminal mais aprimorados sempre estiveram ligados às necessidades pelas quais passaram as sociedades. Dessa forma o advento de organizações criminosas cada vez mais hierarquizadas e estruturadas no Brasil fez com que se adotasse um instituto que tem o seu início atribuído à Itália. A colaboração premiada é um instrumento que está condicionado ao sistema jurídico do país que a adotou, dando uma maior liberdade negocial (common law) ou uma restrição maior (civil law).

Sua denominação, embora muitas vezes confundida, é acertada pela legislação mais atual, que traz em seus dispositivos a denominação do gênero, posto que, embora as formas de se colaborar sejam distintas, os prêmios para a colaboração serão sempre os mesmos. Condiz, ainda, com a sua natureza jurídica, a qual é atribuída pela lei e jurisprudência do Supremo Tribunal Federal como um instrumento de obtenção de provas, e não como prova em si.

Analisando a compatibilidade da colaboração premiada com o Sistema Constitucional Brasileiro, conclui-se pela compatibilidade daquele instrumento apresentado pela Lei 12.850/2013 com as normas que garantem os direitos fundamentais, uma vez que o conjunto apresentado pela citada Lei Federal apresenta não somente direitos materiais, mas também direitos tutórios e aspectos processuais, os quais buscam garantir a não violação de qualquer garantia fundamental. Além disso, a presença do instrumento na História brasileira e no Direito estrangeiro, sem que haja notícia de questionamento de sua constitucionalidade por lá, garantem que a regra é que não haja conflito entre normas referentes à colaboração premiada e normas constitucionais.

Quanto à sua validade utilitária, ou seja, a eficácia do instrumento, a colaboração premiada mostra-se, de fato, um instrumento adaptado às investigações brasileiras e concreto no alcance de seus objetivos. Prova disso é o seu histórico de sucesso no combate às máfias italianas e nos episódios históricos do Brasil. Além disso, em uma visão moderna da colaboração premiada, esta apresenta a possibilidade de abranger questões cíveis, além de criar novas espécies de colaboração, o que amplia a abrangência do instrumento e, portanto, torna-o mais eficaz.

${ }^{22}$ CONSULTOR JURÍDICO. Em parecer, MPF defende prisões preventivas para forçar réus a confessar. 2014. Disponível em: https://www. conjur.com.br/2014-nov-27/parecer-mpf-defende-prisoes-preventivas-forcar-confissoes. Acesso em: 5 jan. 2021. 


\section{Direito \\ Debate}

COLABORAÇÃO PREMIADA: APORTES TEÓRICOS E JURISPRUDENCIAIS, O CASO DO BRASIL E INSERÇÕES NO DIREITO COMPARADO Fernando Soares Gomes - Ian Bernar Santos Barroso - Leandro Luciano Silva Ravnjak

Ainda, discute-se a validade das provas obtidas pelo processo de colaboração premiada. Trata-se de um aspecto essencial da colaboração premiada, uma vez que, como meio de obtenção de provas, não seria válido no Direito brasileiro se as provas colhidas neste processo se tornassem inválidas. Ocorre que a existência de normas processuais e procedimentais garante que não haja vícios nas provas obtidas por colaboração. Havendo desobediência às citadas normas, há, por consequência, invalidade das provas obtidas. Havendo revogação do acordo, por sua vez, as provas permanecem absolutamente válidas. Conclui-se que o instrumento possui a adaptação necessária para que suas provas sejam válidas no processo penal.

A conclusão é de um instrumento que se mostrou necessário e já está incorporado às investigações brasileiras. A análise das adaptações constitucionais, utilitárias e probatórias prova que a colaboração premiada é plenamente válida no Direito brasileiro, na forma que se apresenta atualmente. A colaboração premiada é um instrumento integrado ao cotidiano investigativo e é um meio de acesso a informações que, em regra, não se teria acesso por outros meios, aproximando a Justiça Brasileira da verdade real.

Não obstante as constatações trazidas no corpo deste texto, importa o registro de que a legitimidade do instituto e sua eficiência como meio investigativo estão recorrentemente sendo colocados à prova, especialmente no âmbito da Operação Lava Jato que ainda continua em curso. Tomando por base tal operação, verifica-se que embora o instrumento seja concretamente eficaz, levando à recuperação de valores públicos e à evolução de investigações criminais, é certo que, por vezes, determinados direitos dos colaboradores são desrespeitados, como é o caso do direito ao sigilo do acordo, à preservação da identidade do colaborador e à voluntariedade no compromisso.

O que se conclui é que a aplicação do instituto deve ser aprimorada, especialmente no respeito aos direitos do colaborador, para se evitar a nulidade das provas obtidas, o desperdício do trabalho e a efetividade da aplicação da Lei Penal.

\section{REFERÊNCIAS}

ARAS, Vladimir. Técnicas especiais de investigação. In: CARLI, Carla de. Lavagem de dinheiro: prevenção e controle penal. 2. ed. Porto Alegre: Verbo Jurídico, 2013.

BITTAR, Carlos Barbosa. Delação premiada no Brasil e na Itália: uma análise comparativa. In: Revista Brasileira de Ciências Criminais, n. 88, jan./fev. 2011.

BRASIL. Decreto Lei no. 5.015, de 12 de março de 2004. Disponível em: http://www.planalto.gov.br/ccivil_03/_ato20042006/2004/decreto/d5015.htm. Acesso em: 22 maio 2017.

BRASIL. HC 127.483. Supremo Tribunal Federal. Relator: Min. Dias Toffoli. Publicado em 4/2/2016a.

BRASIL. HC 67.493/PR - Superior Tribunal de Justiça. Relator: Min. Felix Fischer. Publicado em 2/5/2016b.

BRASIL. Lei no 12.850, de 2 de agosto de 2013. Define organização criminosa e dispõe sobre a investigação criminal, os meios de obtenção da prova, infrações penais correlatas e o procedimento criminal; altera o Decreto-Lei no 2.848 , de 7 de dezembro de 1940 (Código Penal); revoga a Lei no 9.034, de 3 de maio de 1995; e dá outras providências. 2013. Disponível em: http:// www.planalto.gov.br/ccivil_03/_ato2011-2014/2013/lei/l12850.htm. Acesso em: 1o dez. 2021.

BRASIL. Lei 13.964/2019, de 24 de dezembro de 2019. Aperfeiçoa a legislação penal e processual penal. 2019. Disponível em: http://www.planalto.gov.br/ccivil_03/_ato2019-2022/2019/lei/L13964.htm. Acesso em: 5 jan. 2021.

CAMPOS, Gabriel Silveira de Queirós. Pleabargaing e justiça criminal consensual: entre os ideais de funcionalidade e garantismo. In: Custos Legis. v. 4, 2012. Disponível em: http://www.prrj.mpf.mp.br/custoslegis/revista/2012_Penal_Processo_Penal_Campos_Plea_Bargaining.pdf. Acesso em: 22 maio 2017.

CASTRO, Antônio Carlos de Almeida. Delação premiada: a nova panacéia na investigação criminal. In: CONFERÊNCIA ESTADUAL DOS ADVOGADOS, 15., 2015. Montes Claros. Painel de Direito Penal. Montes Claros-MG: Salão de Eventos da OAB, $10 / 4 / 2015$.

CEZÁRIO, Maria Maura; VOTRE, Sebastião. Sociolinguística. In: MARTELOTTA, Mário Eduardo et al. Manual de linguística. 2. ed. 3a reimpr. São Paulo: Contexto, 2015.

FERRAJOLI, Luigi. Direito e razão: teoria do garantismo penal. 3. ed. São Paulo: Editora Revista dos Tribunais, 2010.

FIGUEIREDO, Caroline Vieira. As alterações do pacote "anticrime" na Lei de Organizações Criminosas. 2020. Disponível em: https://www.conjur.com.br/2020-jul-13/caroline-figueiredo-pacote-anticrime-lei-organizacoes-criminosas. Acesso em: 5 jan. 2021.

FONSECA, Pedro Henrique Carneiro da. A colaboração premiada. In: De Jure - Revista jurídica do Ministério Público de Minas Gerais, n. 10, p. 247-266, jan./jun. 2008. 


\section{Direito自 Debate}

COLABORAÇÃO PREMIADA: APORTES TEÓRICOS E JURISPRUDENCIAIS, O CASO DO BRASIL E INSERÇÕES NO DIREITO COMPARADO Fernando Soares Gomes - Ian Bernar Santos Barroso - Leandro Luciano Silva Ravnjak

HOUAISS, Antônio; VILLAR, Mauro de Salles. Minidicionário Houaiss da língua portuguesa. 4. ed. Rio de Janeiro, RJ: Objetiva, 2010.

JESUS, Damásio de. Estágio atual da "Delação Premiada" no Direito Penal Brasileiro. In: Revista IOB de Direito Penal e Processual Penal, v. 6, n. 36, fev./mar. 2006.

JESUS, Damásio Evangelista de. Curso de Direito Penal. São Paulo: Saraiva, 2009.

MAIER, Júlio B. J. Derecho processo penal. 2. ed. Buenos Aires: Editora Del Puerto, 2004.

MELO, Valber; BROETO, Felipe Maia. O pacote "anticrime" e seus impactos na colaboração premiada. 2019. Disponível em: https://www.conjur.com.br/2019-dez-29/pacote-anticrime-impactos-colaboracao-premiada\#_ftnref7. Acesso em: 5 jan. 2021. MORELLO, Michele. II Nuovo Processo Penale, parte generale. Padova: Cedam, 2000.

PEREIRA, Frederico Valdez. Valor probatório da colaboração processual (delação premiada). In: Revista CEJ, v. 13, n. 44, jan./ mar. 2009.

REALE, Miguel. Lições preliminares de Direito. 27.ed. São Paulo: Saraiva, 2002.

RODRÍGUEZ, Raúl Carnevali. La criminalidad organizada. Una Aproximación al derecho penal italiano, en particular la responsabilidad de las personas jurídicas y la confiscación. In: Revista lus et Praxis, v. 16, n. 2, 2010. Disponível em: http://dx.doi. org/10.4067/S0718-00122010000200010. Acesso em: 22 maio 2017.

SALTZBURG, Stephen A.; CAPRA, Daniel J. American Criminal Procedure, Cases and Commentary. 5. ed. St. Paul, Minn.: American Casebook Series; West Publishing Co., 1996.

SANTOS, Marcos Paulo Dutra. Colaboração (delação) premiada. Salvador: JusPODIVM, 2016.

SILVA, José Afonso da. Curso de direito constitucional positivo. 39. ed. São Paulo: Malheiros, 2016. p. 217-218.

TASSE, Adel El. Delação premiada: um novo passo para um procedimento medieval. In: Revista dos Tribunais on-line: Ciências Penais, v. 5, jul. 2006. 